Article

\title{
Predictors of Academic Achievement at the End of Middle School: History of Repetition, Social Skills and Social Support
}

\author{
Luana de Mendonça Fernandes ${ }^{1, *}$ \\ Orcid.org/0000-0002-7325-7881 \\ Vanessa Barbosa Romera Leme ${ }^{2}$ \\ Orcid.org/0000-0002-9721-0439 \\ Luciana Carla dos Santos Elias ${ }^{3}$ \\ Orcid.org/0000-0002-1623-0674 \\ Adriana Benevides Soares ${ }^{1}$ \\ Orcid.org/0000-0001-8057-6824 \\ ${ }^{1}$ Universidade Salgado de Oliveira, Niterói, RJ, Brasil \\ ${ }^{2}$ Universidade do Estado do Rio de Janeiro, Rio de Janeiro, RJ, Brasil \\ ${ }^{3}$ Universidade de São Paulo, Ribeirão Preto, SP, Brasil
}

\begin{abstract}
The literature has shown that the socio-emotional development of students can be associated with their repertoire of social skills and perception of social support, while the school repetition experience seems to negatively influence their development and academic achievement at the end of Middle School. In this context, the present study aimed to test a prediction model for academic achievement, having social skills, perception of social support from family, teachers and peers and history of school repetition of students as independent variables. The participants were 311 at the end of Middle School $\left(8^{\text {th }}\right.$ and $9^{\text {th }}$ grade), from public schools in the state of Rio de Janeiro. The data were collectively obtained using the Social Skills Inventory for Adolescents and the Social Support Appraisal Scale. The experience of school repetition, social skills and perceived social support from teachers predicted the academic achievement of students. From these results, the importance of the resources of students and of their context is discussed. These can be used in the school through programs of prevention and promotion of good academic achievement with students, families and teachers.
\end{abstract}

Keywords: Social skills, social support, academic achievement, school repetition, middle school.

\section{Preditores do Desempenho Escolar ao final do Ensino Fundamental: Histórico de Reprovação, Habilidades Sociais e Apoio Social}

\section{Resumo}

A literatura tem indicado que o desenvolvimento socioemocional dos alunos pode ser associado a seu repertório de habilidades sociais e percepção de apoio social, enquanto a experiência de reprovação pa-

* Mailing address: Rua Maestro José Botelho, 2, Apto 203, Vital Brasil, Niterói, RJ, Brazil 24230-410. Phone: (21) 2711-9291. E-mail: luapsi@gmail.com 
rece influenciar negativamente esse desenvolvimento e o desempenho escolar ao final do Ensino Fundamental (E.F.). Diante desse contexto, o presente estudo teve por objetivo testar um modelo de predição para o desempenho escolar, tendo como variáveis independentes as habilidades sociais, a percepção de apoio social da família, professores e pares e o histórico de reprovação dos estudantes. Participaram 311 alunos do $8^{\circ}$ e $9^{\circ}$ ano do E.F., provenientes de escolas públicas do Estado do Rio de Janeiro. Os instrumentos utilizados na coleta de dados foram: Inventário de Habilidades Sociais para Adolescentes e Escala de Percepção de Apoio Social. O histórico de reprovação, as habilidades sociais e percepção de apoio social do professor predisseram o desempenho escolar dos alunos. A partir desses resultados, discute-se a importância dos recursos dos alunos e do seu contexto que poderão ser utilizados na escola através de programas de prevenção e promoção do bom desempenho escolar com os alunos, as famílias e os professores.

Palavras-chave: Habilidades sociais, percepção de apoio social, desempenho escolar, reprovação, Ensino Fundamental.

\section{Los Predictores de Rendimiento Académico al Final de la Educación Primaria: Historial de la Desaprobación, Habilidades Sociales y Apoyo Social}

\section{Resumen}

La literatura ha demostrado que el desarrollo socio-emocional de los estudiantes se puede asociar con su repertorio de habilidades sociales y la percepción de apoyo social, mientras que la experiencia de la desaprobación parece influir negativamente en este desarrollo y el rendimiento académico al final de la educación primaria. En este contexto, el presente estudio tuvo como objetivo poner a prueba un modelo de predicción de rendimiento académico, teniendo como variables independientes las habilidades sociales, la percepción de apoyo social de la familia, los maestros y los compañeros y la historial de la desaprobación de los estudiantes. 311 estudiantes participaron en el grado 8 y 9 de la educación primaria, de las escuelas públicas en el estado de Río de Janeiro. Los instrumentos utilizados en la recogida de datos con los estudiantes fueron: Inventario de Habilidades Sociales para Adolescentes y la Escala de percepción de apoyo social. La experiencia de la desaprobación, habilidades sociales y profesor de apoyo social percibido predice el rendimiento académico de los estudiantes. A partir de estos resultados, se discute la importancia de los recursos de los estudiantes y su contexto que se pueden utilizar en la escuela a través de la prevención y la promoción de programas de actuación buena escuela con estudiantes, familias y profesores.

Palabras clave: Habilidades sociales, apoyo social, rendimiento académico, desaprobación, educación primaria.

Academic achievement is not always achieved by all students throughout the school cycle. Repetitive tasks, lack of relationship between the school curriculum and experiences of students, poor working conditions of teachers and dull and rigid assessments have saturated the school environment, damaging the teachinglearning process (Zambon \& Rose, 2012). Such difficulties faced by students throughout the school trajectory can be analyzed through the school failure phenomenon manifested through problems in learning and behavior, poor academic achievement, repetitions, truancy and abandonment (Dazzani, Cunha, Luttigards, Zucoloto, \& Santos, 2014; Marturano \& Elias, 2016).

Several studies have documented the negative effects of learning difficulties and poor academic performance for the socio-emotional and behavioral development of students, such as lower self-esteem and motivation to study and 
higher levels of stress (D'Abreu \& Marturano, 2010; Inglés, Martínez-González, GarcíaFernández, \& Ruiz-Esteban, 2011). Thus, this study addressed some variables, such as social skills, perceived social support and history of repetition that can contribute to success or failure in the school life of students in the final years of Middle School (M.S.). This period of the academic trajectory is characterized as a critical moment in the school life of students. Data from the Basic Education Development Index report (Ideb, 2013) showed that a total of 473,435 students attending the final years of M.S. abandoned school during 2013. Thus, it seems appropriate to focus on this school transition period to seek to identify factors related to permanence and completion of M.S. and to enrollment in High School (H.S.).

Academic achievement can be understood as the ability of the students to express their learning and knowledge acquired in the teaching-learning process (Perrenoud, 2003). This infers the academic skills of students and has an evaluative character in that students must demonstrate what they have learned in class in their answers in tests and examinations. According to D'Abreu and Marturano (2010), poor academic achievement occurs when students present, in notes or tasks, a result below the level expected for the ages, abilities and potentials of the individuals.

In one concept that goes beyond blaming the students for school failure, academic achievement is understood as a multi-determined phenomenon, influenced by aspects of the students and their family and school contexts, as well as socio-cultural, institutional, political and economic factors (Dazzani et al., 2014; Marturano \& Pizato, 2015; Moreira, Rosário, \& Santos, 2011; Wang \& Holcombe, 2010). Among these variables, research indicates that the social skills and perception of social support of students can be seen as protective factors when faced with adversity (such as history of repetition), positively affecting academic achievement (Azmitia, Cooper, \& Brown, 2009; Dias, Oliveira, Moreira, \& Rocha, 2015; Lopes, Del Prette, \& Del Prette, 2013; Loureiro, Ferreira, \& Santos,
2013; Nunes, Pontes, Silva, \& Dell'Aglio, 2014; Woolley, Kol, \& Bowen, 2009).

Regarding the history of repetition, according to the school census conducted by the Anísio Teixeira National Institute of Educational Studies and Research (Inep) in 2015, the repetition rates were significantly higher in the final years of M.S., which contribute to an age-grade distortion and consequently to school abandonment. In 2015, 170,440 students dropped out of the first year of the M.S., while in 2016 this figure rose to 450,317 students (Inep, 2015).

The Brazilian educational system evaluates its students in various ways, and some states adopt the continued progression system consisting of an assessment by cycles. In this case, in order to advance to a new cycle, the students need to acquire skills and abilities in a cycle (for example, from the $1^{\text {st }}$ to $3^{\text {rd }}$ year, from the $4^{\text {th }}$ to $6^{\text {th }}$ year and from the $7^{\text {th }}$ to $9^{\text {th }}$ year) that is longer than one year or grade. In this mode of evaluation, the students are not held back in any year and can make a recovery through reinforcement classes to advance to a new cycle (Jacomini, 2004). In the state of Rio de Janeiro, where the study was conducted, the evaluation system is by grade, where students can fail a grade/school year, and not by cycle. Thus, students are assessed every year through tests, participation in class and interpersonal skills and must obtain a minimum mean to "pass the grade" (Alves, 2013).

The literature has shown that students who have had to repeat a year present feeling of failure, feel less motivated and envisage fewer prospects regarding continuing to study and the future (Faissol \& Bastos, 2014; Souza, Ponczec, Oliva, $\&$ Tavares, 2012.). School difficulties, including the history of repetition, favor the emergence of behavioral and emotional problems and can produce a lack of belief in the teachers, the parents and the students themselves regarding their ability to learn (Ingul, Klockner, Silverman, \& Nordahl, 2012). Ortigão and Aguiar (2013) showed that students with low academic achievement are generally those who have experienced one or more episodes of school repetition. Similarly, studies (Alves, Ortigão, \& Franco, 2007; Ban- 
deira, Rocha, Pires, Del Prette, \& Del Prette, 2006; Jacomini, 2009) have shown that students with a history of repetition can reproduce the situation of school failure in the ensuing years of academic life. Nunes et al. (2014) conducted a study with 610 young people in M.S. and H.S., in order to investigate the relationship between history of school repetition, perceptions about the school and future expectations. The results showed that almost $50 \%$ of the students had a history of school repetition and, of these, 3.9\% had been expelled from the school. The results also indicated that the higher the repetition rate, the lower the expectation of entering university and, therefore, the previous experience of school repetition was a psychosocial risk factor. However, if the history of repetition adversely affects academic achievement, resources of students and their contexts, such as social skills and social support from the family, teachers and peers can act as protective factors.

Social skills can be understood as the behaviors of an individual, socially acceptable within the context of a culture and a historical time, that favor interpersonal relationships based on respect for human rights (Del Prette \& Del Prette, 2010). Social skills of students, such as asking for help, offering support, initiating and maintaining conversation and refusing requests without harming the relationship, among others, have repeatedly shown to be positively associated with good academic achievement (Hall \& DiPerna, 2016; Lopes et al., 2013). Marturano and Pizato (2015), when testing a predictive model, found that the social skills of students in the $3^{\text {rd }}$ year of Elementary School explained about $40 \%$ of the variability in academic achievement in the $5^{\text {th }}$ year.

Studies suggest that students with deficits in social skills and low emotional control skills demonstrated greater difficulty socializing with peers and teachers and could experience academic failure and later a premature exit from school (Beauchamp \& Anderson, 2010; Elias \& Marturano, 2014; Feitosa, Del Prette, \& Del Prette, 2012). In general, the greater the social skills of students the better the academic achievement
(Caemmerer \& Keith, 2015; Cia \& Costa, 2012; Marturano \& Pizato, 2015; Womack, Marchant, \& Borders, 2011).

Studies have shown that social support from the school (teachers and other actors in the educational context) and from the family favor the development of both the social skills and the academic skills of students (Marturano \& Pizato, 2015; Wang \& Holcombe, 2010). This social support assists students in times of school transition, minimizing stress and promoting the adaptation of students to the new context (Langenkamp, 2010).

There is a consensus in the literature regarding terminological, operational and theoretical aspects of social support (Gonçalves, Pawlowski, Bandeira, \& Piccinini, 2011). In this study, the concept adopted was that of perceived social support defined by Vaux et al. (1986) as the way the person perceives the acceptance and support of significant others, such as family members, colleagues and teachers, and how that influences their behaviors, thoughts and feelings. The perception of social support has a positive impact on the physical and psychological well-being, self-esteem, the self-concept and motivation for success in many sectors of life during adolescence, for example, academic achievement (Azmitia et al., 2009; Dias et al., 2015; Woolley et al., 2009).

The social support received and perceived by the person changes constantly throughout the life cycle (Gonçalves et al., 2011). However, in adolescence the possibility of participation in multiple contexts and the greater autonomy of adolescents become relevant to identify the characteristics of different sources of social support (Squassoni \& Matsukura, 2014). In this sense, studies (Antunes \& Fontaine, 2008; Olsson, Hagekull, Giannotta, \& Ahalander, 2016) indicate three important sources of support: family; friends; and people in the school, such as teachers.

In adolescence, despite the greater proximity to peers, studies have found that family members do not cease to be references of security for the adolescents, being characterized as social 
support complementary to that perceived from the friends (Alves \& Dell'Aglio, 2015a; Amparo, Galvão, Alves, Brasil, \& Koller, 2008; Olsson et al., 2016; Squassoni \& Matsukura, 2014). The perception of social support from the family enables adolescents to feel secure and establish contacts in other contexts, leading to increased self-esteem, well-being and feelings of acceptance that facilitate the integration with peers (Olsson et al., 2016; Tomé \& Matos, 2012).

In the school context, the social support of friends can have a positive influence on academic achievement because the adolescents perceive themselves to be in a group that they identify with and can draw upon faced with the difficulties missed by teachers (Dias et al., 2015; Tomé \& Matos, 2012). Thus, the friends would be a source of learning of school skills and social skills, serving as social sustenance and possibly having a positive influence on the choice of a healthier lifestyle (Del Prette \& Del Prette, 2009; Wang \& Holcombe, 2010). However, the relationship with peers has also been linked to risky behavior in adolescence, such as substance abuse and delinquency (Alves \& Dell'Aglio, 2015b; Olsson et al., 2016).

The school can be an environment that not only provides adolescents with academic content, but can also be a predictable place with clear rules that help them feel protected (Bokhorst, Sumter, \& Westenberg, 2010; Dias et al., 2015; Machado, Yunes, \& Silva, 2014). Thus, scientific evidence has shown that the perception of social support from teachers is associated with increased levels of well-being, self-esteem and academic achievement, as well as less likelihood of developing behavioral problems (Dotterer \& Lowe, 2011; Tian, Zhao, \& Huebner, 2015). In this sense, studies suggest that there is a positive influence of the school on the academic achievement, as students feel more motivated and interested in academic activities when the classroom contexts promote their interpersonal relationship needs (Amparo et al., 2008; Dias et al., 2015; Dotterer \& Lowe, 2011).

When the school contexts, family and friendly relations provide more social support there is better socio-emotional development of students with poor academic performance, giving them better conditions to persist in studies without abandoning the school (Hymel \& Ford, 2012). Conversely, low scores of student associated with limited family support, lack of emotional connection of the students with the school and with the teachers and poor relationships with colleagues would be the most influential factors for school truancy (Dias et al., 2015; Langenkamp, 2010).

Poor academic achievement may be associated with various aspects present in the school and family contexts of the students and influenced by educational policies (França \& Gonçalves, 2003; Wang \& Holcombe, 2010). In Brazil, about $39 \%$ of students leave school before completing M.S., especially those with histories of repetition (Oliveira \& Saraiva, 2015). Some studies have found a relationship between social support from family, teachers and friends and academic success, showing that the social context influences academic achievement (Azmitia et al., 2009; Dias et al., 2015; Woolley et al., 2009). With this, the more social support the students have the more easily they can meet the challenges of the school trajectory (Machado et al., 2014).

Despite this evidence, a review of the literature showed that, in the Brazilian context, there are no studies that sought to investigate the impact of perceived social support and the social skills of students on academic achievement during the final years of M.S. It was possible to identify a gap in the knowledge about this moment of the school cycle, which, as noted above, presents a significant amount of abandonment. In this context, the present study aimed to test a prediction model for academic achievement, having social skills, perception of social support from family, teachers and peers and the history of repetition of the students as independent variables. Thus, with the information from the present study it is expected to be able to plan intervention programs with students, their families and their teachers in order to expand their interpersonal resources. 


\section{Method}

\section{Participants}

A correlational predictive study was performed with a sample selected by convenience. The participants were 311 students, of both genders, with a mean age of 14.03 years $(S D=$ 1.23), who were attending the final two years of the M.S. (176 students of the $8^{\text {th }}$ grade and 142 of the $9^{\text {th }}$ grade) from three public schools in the state of Rio de Janeiro. The schools presented similar Ideb assessments, corresponding to the year 2013: school $1=4.1$; school $2=4.0$; school $3=4.0$.

\section{Instruments}

Social Skills Inventory for Adolescents (SSIA-Del-Prette). Developed by Del Prette and Del Prette (2009) to evaluate the social skills of adolescents from their self-reports about everyday situations. It presents 38 items that cover different social skills. The responses are given on a Likert type scale of five points $(0=$ never to 4 = always) and it is divided into six factors, with the following internal consistency indices in this study: (1) Empathy ("When noticing a (a) colleague is sad or having some difficulty in school, offering support or help", $\alpha=0.81$ ); (2) Self-control ("When criticized by parents and teachers can calm down and control the irritation", $\alpha=0.77$ ); (3) Civility ("When someone does something good can praise them and give thanks when receiving praise", $\alpha=0.83$ ); (4) Assertiveness ("If feeling that it is wrong to do something, even when pressured by colleagues, not doing what the colleagues want", $\alpha=0.71$ ); (5) Affective approach ("When wanting to make friends, inviting the person to an event or activity”, $\alpha=0.61$ ); (6) Social Resourcefulness ("In school making oral presentations in groups when requested", $\alpha=0.57$ ); total of the instrument $\alpha$ $=0.91$.

Social Support Appraisals Scale (SSA). This instrument was developed by Vaux et al. (1986) for the American context, to examine the perception of social support of children and adolescents in relation to family and friends. The scale was validated for the population of Brazilian adolescents by Squassoni and Matsukura (2014). It consists of 30 items arranged in a Likert type scale of six points $(1=$ strongly disagree to $6=$ strongly agree) and includes four factors, with the following internal consistency indices in this study: (1) Perception of social support from family ("My family cares about me a lot", $\alpha=0.78$ ); (2) Perception of social support from friends ("I feel very connected to my friends", $\alpha=0.74$ ); (3) Perception of social support from teachers ("Most of my teachers respect me a lot", $\alpha=0.69$ ); (4) Perception of social support from others in general ("People, in general, like me", $\alpha=0.72$ ); total of the scale $\alpha=0.81$. The general perception factor was not used in this study as the aim was to investigate specific social support.

Demographic and Socioeconomic Status Information Questionnaire. This was developed for the study to investigate social and demographic information, and was divided into three parts: (a) general application information; (b) information about the participants (name, age, gender, color and history of school repetition - whether had already repeated a year and how many times); (c) information about the family (number and indication of who lived with the students). The Brazil Economic Classification Criterion (Associação Brasileira de Empresas de Pesquisa [ABEP], 2011) was also used. This assesses socioeconomic status and allows the stratification of families, in order of decreasing purchasing power in five classes: A (A1 and $\mathrm{A} 2), \mathrm{B}$ (B1 and B2), C, D and E.

\section{Procedures}

Data Collection. After delivery of the consent form and the terms of assent, signed by the legal guardians of the students and by the students themselves, respectively, the data collection was carried out collectively in the classroom of the students, at a time previously agreed with the teachers. At the beginning of each application (mean duration 50 minutes), the aims of the study, the guarantee of confidentiality of the data collected and the voluntary nature of their participation were explained to the students. The 
project, consistent with Resolution 466/12 of the National Health Council, was approved by the Research Ethics Committee of the University in which the study was conducted.

Data Analysis. Data analysis was performed using the Statistical Package for the Social Sciences software for Windows (SPSS, version 18.0). First, the normality of the sample distribution was confirmed. Next, there was the exploration of differences related to the gender of students (chi-square test) and descriptive statistics (frequencies and percentages) of the history of school repetition variable. Then the correlation between the study variables was calculated (Pearson's $r$ ). Finally, the independence and multicolinearity assumptions were tested and confirmed (Marôco, 2011), with the multiple linear regression analysis (stepwise method) then carried out. Academic achievement was the dependent variable obtained by the sum of the scores of all subjects (Portuguese, English, Mathematics, History, Geography, Physics, Chemistry and Science) computed in the Report of Final Results of the first half of the year in the schools where the data was collected. This sum was divided by the total number of disciplines, creating a general index called the final mean which ranged from 0.0 to 10.0 . The history of school repetition; the total SSIA-Del-Prette; the three factors of the SSA (perceived social support from friends, perceived social support from family and perceived social support from teachers) were considered as independent variables. A dummy variable was created for the history of school repetition that, according to Marôco (2011), is a method to "quantify" variables that indicate the presence or absence of an attribute: repetition experience yes $=1$; no $=0$.

\section{Results}

\section{Demographic Information}

There was an even distribution in relation to the gender of the participants (173 girls and 145 boys $-\chi^{2}=2.46 ; p=.11$ ). Regarding the color declared by the students, it was found that $43.08 \%$ of the sample reported being mixed race, $29.87 \%$ white, $20.44 \%$ black, $4.09 \%$ yel- low, $2.52 \%$ indigenous. With regard to the socioeconomic status of the families, $37.10 \%$ belonged to class B2, $28.90 \%$ to class $\mathrm{C} 1,20.40 \%$ to class $\mathrm{B} 1,8.50 \%$ to Class $\mathrm{C} 2,4.40 \%$ to Class A2, $0.30 \%$ to class D and $0.30 \%$ to class A1.

Regarding the history of school repetition, 200 students $(64.3 \%)$ reported never having repeated a year, while $111(35.7 \%)$ indicated that they had had to repeat one year $(n=68), 38$ students two years and 5 students three or more years. The data showed that the male adolescents $(n=60)$ repeated years more than the females $(n=50)$, however, the chi-squared test indicated no significant difference in relation to gender $\left(\chi^{2}\right.$ $=0.73 ; p=.39)$. Students who reported having repeated a year were aged between 15 and 17 years.

\section{Analysis of Correlation and Regression}

The results showed a moderate negative correlation between repetition and the academic achievement of the students $(r=-0.4 ; p=.001)$. With the exception of perceived social support from friends, weak to moderate positive correlations were found between the academic achievement of students and the total social skills of the students $(r=0.26 ; p=.001)$, perceived social support from family $(r=0.18 ; p=.002)$ and perceived social support from teachers $(r=0.22 ; p$ $=.001$ ).

Table 1 shows the variables associated with the academic achievement of the students. The significant model $[F(3.30)=29.44 ; p=.01]$ presented in Table 1 showed that the history of school repetition, total social skills and the perception of social support from teachers explained $22 \%$ of the variability of the academic achievement of the students. The results indicated that the history of repetition of the student had greater weight regarding academic achievement. The value of the negative standardized coefficient $(\beta)$ indicated a negative association between repetition and academic achievement. The social skills of the students and their perception of social support from teachers correlated positively with the academic achievement of the students. 
Table 1

Regression Model for the Prediction of the Academic Achievement of Students at the End of Middle School

\begin{tabular}{cccccc}
\hline Predictors & $M(S D)$ & $B(\mathrm{SE}-B)$ & $\beta$ & $95 \% \mathrm{CI}$ & $R^{2}$ \\
\hline History of Repetition & $0.36(0.48)$ & $-1.00(0.14)$ & $-0.36^{*}$ & {$[-1.28 ;-0.72]$} & $0.16^{*}$ \\
Social Skills & $90.68(24.39)$ & $0.01(0.01)$ & $0.16^{*}$ & {$[0.03 ; 0.01]$} & $0.20^{*}$ \\
Social Support from Teachers & $27.23(6.75)$ & $0.02(0.01)$ & $0.13^{*}$ & {$[0.01 ; 0.04]$} & $0.21^{*}$ \\
\hline
\end{tabular}

Note. $\mathrm{N}=311 . B=$ non-standard regression coefficient, $\mathrm{SE} B=$ Standard Error of the non-standard regression coefficient; $\beta=$ standardized regression coefficient; $\mathrm{CI}=$ confidence interval; $R^{2}=$ adjusted determination coefficient.

${ }^{*} p<.01$.

\section{Discussion}

The final years of Middle School (M.S.) are a time in school cycle that is critical in the academic trajectory, as students face many difficulties involving socioeconomic, political and interpersonal factors that can lead to poor academic achievement and hence increase the chance of abandonment and truancy (Inep, 2015). However, few studies have investigated the final years of M.S. Thus, this study aimed to investigate the impact of variables of the students (social skills of the students and history of school repetition) and of the context (perceived social support) on academic achievement in the final two years of M.S.

The results indicated that $35 \%$ of the sample had repeated a year at least once, with no difference between genders. Although Nunes et al. (2014) also did not find differences between boys and girls, the authors found that about $50 \%$ of the study participants had experienced school repetition. The study of Ortigão and Aguiar (2013) also showed that by the $5^{\text {th }}$ year of EE, $40 \%$ of the girls had already repeated a year, while for the boys this percentage was almost $60 \%$.

The study data showed that students who had repeated a year were aged between 15 and 17 years. According to the Law of Directives and Bases of National Education (Law No. 9.394, 1998), Elementary School includes students aged 6 to 14 years, while H.S. includes students aged 15 to 17 years. Thus, there is the presence of an age-grade distortion among the students of this sample with a history of school repetition because their ages were compatible with being in H.S. In the study by Souza et al. (2012) the authors found that truancy during the school year is higher among students that presented ages incompatible with the grade of study. That is, students with a history of repeating years show greater tendency to abandon school during the school year than from one year to another. Nunes et al. (2014) also found that the school repetition was negatively associated with the expectations of the students to complete H.S. and enter Higher Education.

This draws attention to the possibility of students entering a cycle of school failure that affects both the quality of the permanence and completion of M.S., as well as the entry into H.S. (Alves et al., 2007; Bandeira et al., 2006; Jacomini, 2009). It should be noted that failure or success in the school learning process is less frequently determined by individual issues than by interactive, educational, institutional and political mechanisms (Dazzani et al., 2014). Thus, the focus of the view of poor academic achievement should not be based on the psychological or maturational difficulties of the students, but on the investigation of the relational processes among students and the family, school and institutional contexts (Marturano \& Elias, 2016).

The results of the correlation analyses are in agreement with the literature, indicating that a history of school repetition can negatively influence the academic achievement of students at the end of M.S. (Womack et al., 2011). Similar to other studies, the resources of the students, such as social skills (Cia \& Costa, 2012; Feitosa et al., 2012; Lopes et al., 2013; Hall \& DiPerna, 2016; 
Marturano \& Pizato, 2015; Milson \& Glanville, 2010) and perceived social support from family and teachers (Azmitia et al., 2009; Dias et al., 2015; Woolley et al., 2009) were positively associated with the academic achievement of students. In the context of school transition from M.S. to H.S., social support from family, friends and teachers resulted in good academic achievement for the students (Langenkamp, 2010). Marturano and Pizato (2015) highlighted the importance of support networks and that these, associated with the resources of the student (social skills), can mitigate the negative impacts that this transition can cause.

The results of the regression model tested indicated that the academic achievement at the end of M.S. was predicted, in order of influence, by the history of school repetition, social skills and perceived social support from teachers, together explaining $22 \%$ of the performance variability. The history of repetition was the variable with the greatest weight regarding the academic achievement of the students, presenting a negative association with the means of the marks obtained by the students. Other studies have found similar results, indicating that school repetition is a risk factor for the socio-emotional and academic development of students, leading to agegrade distortions and abandonment of school (Alves et al., 2007; Bandeira et al., 2006; Jacomini, 2009).

According to Ortigão and Aguiar (2013), this is because the experience of school repetition affects the academic activities and interpersonal relationships of students, who tend to be unmotivated and consequently abandon school. Often the teachers themselves and colleagues stigmatize and discriminate against "repeating" students (Faissol \& Bastos, 2014). Thus, these students end up isolating themselves (or are isolated), tending not to participate in the proposed activities and having no interest in performing the proposals related to learning (Almeida \& Sartori, 2012).

According to the previous literature, the social skills of students positively predict their academic achievement. Several studies have shown that a good social skills repertoire helps academ- ic competence and good academic achievement, as social skills are features of the individual that help the learning process (Caemmerer \& Keith, 2015; Hall \& DiPerna, 2016; Zambon \& Rose, 2012). To report feelings, ask for help and to give and receive support are skills that can help students to express their feelings faced with poor academic achievement and to ask for help from friends, parents and teachers to get out of this vulnerable situation (Lopes et al., 2013; Womack et al., 2011; Zambon \& Rose, 2012). Therefore, social skills stimulate the decision-making capacity and the reduction of dysfunctional behaviors and risk, helping the academic achievement (Feitosa et al., 2012).

Among the three types of social support tested in the regression model, only the perception of social support from teachers was a positive predictor of the academic achievement of the students. Although interpersonal relations diversify in adolescent, studies have found that adolescents perceive more social support from the family than from peers and teachers (Alves \& Del'Aglio, 2015a; Amparo et al., 2008; Olsson et al., 2016; Squassoni \& Matsukura, 2014). Thus, it can be assumed that even if teachers are perceived as a limited source of social support, their influence on academic achievement is important and needs to be encouraged (Alves \& Dell'Aglio, 2015a; Bolsoni-Silva et al., 2013; Dias et al., 2015), especially in the transition from the M.S. to H.S. In this sense, Berry and O'Connor (2010) conducted a longitudinal study of 1364 children from kindergarten to the $6^{\text {th }}$ year of M.S. and found a positive correlation between the quality of the teacher-student relationship and the social skills of students with internalizing problems.

Although the perception of social support from family and friends did not enter the regression model, this support should be encouraged. The perception of social support from the family helps students to face the challenges and feel more accepted and more protected (Squassoni \& Matsukura, 2014). The affective communication of the family assists students in socialization, in expanding the contact network and protects them from risk situations, such as friendships that con- 
tribute to risk behaviors (Alves \& Dell'Aglio, 2015b; Olsson et al., 2016). Adolescents who have more contact and a good relationship with their parents are found to be happier and more satisfied with life (Tomé \& Matos, 2012). Thus, the perception of social support from the family associated with a reciprocal relationship with good communication and with a positive relationship contributes to the student having healthier behaviors and good academic achievement (Azmitia et al., 2009; França \& Gonçalves, 2003).

Likewise, friendships can help students who have poor academic achievement, for example, asking other colleagues about a doubt as well as resorting to the teacher. Added to this, students have the same language and are in the same stage of development (in this case adolescence), which can facilitate the exchange of experiences (Tomé $\&$ Matos, 2012). Thus, it could be suggested that reciprocal friendly relationships contribute to good educational results of students in their daily lives (Wang \& Holcombe, 2010), although some friendly relationships negatively affect the development of students with, for example, drug use, violence and aggressive behavior (Alves \& Dell'Aglio, 2015b). Therefore, all the support networks are important to assist the development, because if one does not provide support, another can, so that the subject feels accepted. Thus, it is not enough for students to feel supported, but they also require material, social and affective resources from their support networks to promote their healthy development (Machado et al., 2014).

\section{Final Considerations}

In general, the results indicated that social skills (resources of the students) and perceived social support from teachers (resources of the school environment) impact positively on the academic achievement of students and can help them throughout their school trajectory, especially in times of transition, such as the end of M.S. Some limitations of this study should be considered. First, the results are specific to a particular sample that was selected by convenience from some public schools located in the state of Rio de Janeiro.

Second, the data collected related to the perceptions of the students and therefore it would be interesting if future studies included information obtained from other informants, such as parents and teachers. Third, the value of the regression coefficient found was considered small, which indicates that future studies should include other variables, such as school climate, parental educative practices and perception of school stressors. Finally, it must be considered that the academic achievement was measured through the mean of the school subjects, which is not a standardized measure of skills. On one hand, this measure provides contextual data of the educational reality of the schools studied, while on the other it limits the comparison with other places. Thus, other performance measurement instruments could be used in future studies, such as the Brazil Exam or the Academic Achievement Test, or even academic competence measures, such as the teachers' version of the Social Skills Rating System (SSRS).

The educational trajectory is a multifactorial phenomenon that is influenced by individual, contextual (family, school and community), social, economic and political variables. There must be investment in public educational policies, especially in the final years M.S., to improve the quality of the education, as well as the structural and wage conditions of the teachers. Thus, the study showed some variables that can be the focus of future intervention programs with students, families and educators. These interventions can assist students with poor academic achievement and history of repetition and thus keep them in school to complete basic education.

\section{References}

Almeida, T. F. S., \& Sartori, J. (2012). A relação entre desmotivação e o processo de ensino-aprendizagem. Revista Monografias Ambientais, 8(8), 1870-1886. Retrieved from http://cascavel.ufsm. br/revistas/ojs-2.2.2/index.php/remoa/index

Alves, A. M. L. (2013). Os ciclos: A experiência da organização do ensino no Rio de Janeiro e 
Niterói. Educação e Foco, 17(3), 87-115. Retrieved from http://www.ufjf.br/revistaedufoco/ files/2013/10/cap-04.pdf

Alves, C. F., \& Dell'Aglio, D. D. (2015a). Percepção de apoio social de adolescentes de escolas públicas. Revista de Psicologia da IMED, 7(2), 89-98. doi:10.18256/2175-5027/psico-imed. v7n2p89-98

Alves, C. F., \& Dell'Aglio, D. D. (2015b). Apoio social e comportamentos de risco na adolescência. Psico, 46(2), 165-175. doi:http://dx.doi. org/10.15448/1980-8623.2015.2.18250

Alves, F., Ortigão, I., \& Franco, C. (2007). Origem social e risco de repetência: Interação entre raça-capital econômico. Cadernos de Pesquisa, 37(130), 161-180. doi:10.1590/S010015742007000100008

Amparo, D. M., Galvão, A. C. T., Alves, P. B., Brasil, K. T., \& Koller, S. H. (2008). Adolescente e jovens em situação de risco psicossocial: Redes de apoio social e fatores pessoais de proteção. Estudos de Psicologia (Natal), 13(2), 165-174. doi:10.1590/S1413-294X2008000200009

Anísio Teixeira National Institute of Educational Studies and Research. (2015). Censo escolar 2015. Brasília, DF: Author. Retrieved from http://portal.inep.gov.br/basica-censo

Antunes, C., \& Fontaine, A. M. (2008). Percepção de apoio social na adolescência: Análise fatorial confirmatória da escola Social Support Appraisails. Paideia (Ribeirão Preto), 15(32), 355-366. Retrieved from http://sites.ffclrp.usp.br/paideia/ artigos/32/04.htm

Associação Brasileira de Empresas de Pesquisa. (2011). Critério de classificação econômica Brasil. Retrieved from http://www.abep.org/ criterio-brasil

Azmitia, M., Cooper, C. R., \& Brown, J. R. (2009). Support and guidance from families, friends, and teachers in Latino early adolescents' math pathways. Journal of Early Adolescence, 29(1), 142-169. doi:10.1177/0272431608324476

Bandeira, M., Rocha, S. S., Pires, L. G., Del Prette, Z. A. P., \& Del Prette, A. (2006). Competência acadêmica de crianças do Ensino Fundamental: Características sociodemográficas e relação com habilidades sociais. Interação em Psicologia, 10(1), 53-62. Retrieved from http://ojs.c3sl. ufpr.br/ojs/index.php/psicologia/article/viewFile/5773/4209
Basic Education Development Index Report. (2013). Brasília, DF: Ministério da Educação. Retrieved from http://ideb.inep.gov.br/resultado

Beauchamp, M. H., \& Anderson, V. (2010). Social: An integrative framework for the development of social skills. Psychological Bulletin, 136(1), 39-64. doi:10.1037/a0017768

Berry, D., \& O`Connor, E. (2010). Behavioral risk, teacher-child relationships, and social skill development across middle childhood: A child-byenvironment analysis of change. Journal of Applied Developmental Psychology, 31(1), 1-14. doi:10.1016/j.appdev.2009.05.001

Bokhorst, C. L., Sumter, S. R., \& Westenberg, P. M. (2010). Social support from parents, friends, classmates, and teachers in children and adolescents aged 9 to 18 years: Who is perceived as most supportive? Social Development, 19(2), 417426. doi:10.1111/j.1467-9507.2009.00540.x

Bolsoni-Silva, A. T., Verdu, A. C. M. A., Carrara, K., Melchiori, L. E., Leite, L. P., \& Calais, S. L. (2013). Ampliando comportamentos pró-éticos dos alunos: Relato de pesquisa e intervenção com educadores do Ensino Fundamental. Temas em Psicologia, 21(2), 347-359. doi:10.9788/ TP2013.2-04

Caemmerer, J. M., \& Keith, T. Z. (2015). Longitudinal, reciprocal effects of social skills and achievement from kindergarten to eighth grade. Journal of School Psychology, 53, 265-281. doi:10.1016/j.jsp.2015.05.001

Cia, F., \& Costa, C. L. S. (2012). Desempenho acadêmico nas séries do ensino fundamental: Relação com o desenvolvimento social. Psicologia e Argumento, 30(68), 109-118. Retrieved from http://www2.pucpr.br/reol/pb/index.php/ pa?dd1 $=5889 \& d d 99=$ view $\& d d 98=$ pb

D’Abreu, L. C. F., \& Marturano, E. M. (2010). Associação entre comportamentos externalizantes e baixo desempenho escolar: Uma revisão de estudos prospectivos e longitudinais. Estudos de Psicologia (Natal), 15(1), 43-51. doi:http://dx.doi. org/10.1590/S1413-294X2010000100006

Dazzani, M. V. M., Cunha, E. de O., Luttigards, P. M., Zucoloto, P. C. S. V., \& Santos G. L. (2014). Queixa escolar: Uma revisão crítica da produção científica nacional. Revista Quadrimestral da Associação Brasileira de Psicologia Escolar e Educacional, 18(3), 421-428. doi:10.1590/2175$3539 / 2014 / 0183762$ 
Del Prette, Z. A. P., \& Del Prette, A. (2009). Inventário de Habilidades Sociais para adolescentes (IHSA-DEL-PRETTE): Manual de aplicação, apuração e interpretação. São Paulo, SP: Casa do Psicólogo.

Del Prette, Z. A. P., \& Del Prette, A. (2010). Habilidades sociais e análise do comportamento: Proximidade histórica e atualidades. Revista Perspectivas, 1(2), 104-115. Retrieved from http://porteiras.r.unipampa.edu.br/portais/ cap/files/2013/12/TREINAM-HABLDDSOCIAIS-104-115_RP_2010_01_02.pdf

Dias, A., Oliveira, J. T., Moreira, P. A. S., \& Rocha, L. (2015). Percepção dos alunos acerca das estratégias de promoção do sucesso educativo e envolvimento com a escola. Estudos de Psicologia (Campinas), 32(2), 187-199. doi:10.1590/0103-166X2015000200004

Dotterer, A. M., \& Lowe, K. (2011). Classroom context, school engagement, and academic achievement in early adolescence. Journal Youth Adolescence, 40, 1649-1660. doi:10.1007/ s10964-011-9647-5

Elias, L. C. S., \& Marturano, E. M. (2014). “Eu posso resolver problemas" e oficinas de linguagem: Intervenções para queixa escolar. Psicologia: Teoria \& Pesquisa, 30(1), 35-44. doi:10.1590/ S0102-37722014000100005

Faissol, K., \& Bastos, M. C. (2014). Projeto Refazer: Uma reflexão da reprovação a partir do olhar do aluno. Revista de Psicologia da Criança e do Adolescente, 5(1), 201-210. Retrieved from http://revistas.lis.ulusiada.pt/index.php/rpca/article/view/1132

Feitosa, F. B., Del Prette, Z. A. P., \& Del Prette, A. (2012). Social skills and academic achievement: The mediating function of cognitive competence. Temas em Psicologia, 20(1), 61-70. Retrieved from http://pepsic.bvsalud.org/pdf/tp/v20n1/ v20n1a06.pdf

França, M. T. A., \& Gonçalves, F. O. (2003). Sistemas públicos de ensino fundamental e a perpetuação da desigualdade: Democracia e qualidade educacional como promotoras de justiça social. Revista Brasileira de Estudos de População, 29(2), 303-322. Retrieved from www.scielo.br/ pdf/rbepop/v29n2/a06v29n2.pdf

Gonçalves, T. R., Pawlowski, J., Bandeira, D. R., \& Piccinini, C. A. (2011). Avaliação de apoio social em estudos brasileiros: Aspectos conceituais e instrumentos. Ciência \& Saúde Coletiva, 16(13), 1755-1769. doi:10.1590/ S1413-81232011000300012

Hall, G. E., \& DiPerna, J.C. (2016). Childhood social skills as predictors of middle school academic adjustment. Journal of Early Adolescence, 3(4), 1-27. doi:10.1177/0272431615624566

Hymel, S., \& Ford, L. (2012). Conclusão escolar e sucesso acadêmico: O impacto da competência socioemocional precoce. In T. R. E. Tremblay, M. Boivin, \& M. P. RDeV (Eds.), Enciclopédia sobre o Desenvolvimento na Primeira Infância (pp. 1-8). Montreal: Centre D'excellence pour le Développement des Jeunes Enfants. Retrieved from http://www.enciclopedia-crianca.com/ sites/default/files/textes-experts/pt-pt/2612/ conclusao-escolar-e-sucesso-academico-oimpacto-da-competencia-sociomocionalprecoce-.pdf

Inglés, C. J., Martínez-González, A. E., GarcíaFernández, J. M., \& Ruiz-Esteban, C. (2011). Conducta prosocial y motivación académica en estudiantes españoles de Educación Secundaria Obligatoria. Universita Psychologica, 10(2), 451-465. Retrieved from http://revistas. javeriana.edu.co/index.php/revPsycho/article/ view/756

Ingul, M. J., Klockner, C. A., Silverman, W. K., \& Nordahl, H. M. (2012). Adolescent school absenteeism: Modelling social and individual risk factors. Child and Adolescent Mental Health, 17(2), 93-100. doi:10.1111/j.1475-3588.2011.00615

Jacomini, M. A. (2004). A escola e os educadores em tempo de ciclos e progressão continuada: Uma análise das experiências no estado de São Paulo. Educação e Pesquisa, 30(3), 401-418. Retrieved from www.scielo.br/pdf/ep/v30n3/a02v30n3. pdf

Jacomini, M. A. (2009). Educar sem reprovar: Desafio de uma escola para todos. Educação $e$ Pesquisa, 35(3), 557-572. Retrieved from http:// www.scielo.br/pdf/ep/v35n3/10.pdf

Langenkamp, A. G. (2010). Academic vulnerability and resilience during the transition to high school: The role of social relationships and district context. Sociology of Education, 83(1), 1-19. doi:10.1177/0038040709356563

Law No. 9.394. (1998). Law of Directives and Bases of National Education. Brasília, DF. Retrieved from www.planalto.gov.br/ccivil 03/leis/L9394 
Lopes, D. C., Del Prette, Z. A. P., \& Del Prette, A. (2013). Recursos multimídia no ensino de habilidades sociais a crianças de baixo rendimento acadêmico. Psicologia: Reflexão $e$ Crítica, 26(3), 451-458. doi:10.1590/S010279722013000300004

Loureiro, C., Ferreira, M. M. F., \& Santos, M. R. (2013). Identificação dos fatores determinantes no desenvolvimento das competências sociais dos adolescentes. Revista de Enfermagem, 3(10), 79-88. doi:10.12707/RIII12114

Machado, J. A., Yunes, M. A M., \& Silva, G. F. (2014). A formação continuada de professores em serviço na perspectiva da abordagem ecológica do desenvolvimento humano. Revista Contrapontos, 14(3), 512-526. doi:10.14210/ contrapontos.v14n3.p512-526

Marôco, J. (2011). Analise estatística com o SPSS Statistics $\left(5^{\text {th }}\right.$ ed.). Pero Pinheiro, Portugal: ReportNumber.

Marturano, E. M., \& Elias, L. C. S. (2016). Família, dificuldades no aprendizado e problemas de comportamento em escolares. Educar em Revista, 59, 123-139. doi:10.1590/01044060.44617

Marturano, E. M., \& Pizato, E. C. G. (2015). Preditores de desempenho escolar no $5^{\circ}$ ano do Ensino Fundamental. Psico, 46(1), 16-24 Retrieved from http://revistaseletronicas.pucrs.br/ojs/ index.php/revistapsico/article/view/14850

Milson, A., \& Glanville, J. L. (2010). Factors mediating the relationship between social skills and academic grades in a sample of students diagnosed with learning disabilities or emotional disturbance. Remedial and Special Education, 31(4), 241-251. Retrieved from http://rse. sagepub.com/content/31/4/241

Moreira, J. O., Rosário, A. B., \& Santos, A. P. (2011). Juventude e adolescência: Considerações preliminares. Psico, 42(4), 457-464. Retrieved from http://revistaseletronicas.pucrs.br/ojs/index.php/ revistapsico/article/viewArticle/8943

Nunes, T. G., Pontes, F. A. R., Silva, L. I. C., \& Dell'Aglio, D. (2014). Fatores de risco e proteção na escola: Reprovação e expectativas de futuro de jovens paraenses. Revista Quadrimestral da Associação Brasileira de Psicologia Escolar e Educacional, 18(2), 203-210. doi:http://dx.doi. org/10.1590/2175-3539/2014/0182732
Oliveira, D. A., \& Saraiva, A. M. A. (2015). A relação entre educação e pobreza: A ascensão dos territórios educativos vulneráveis. Revista Educação Temática Digital, 17(3), 614-632. Retrieved from http://periodicos.sbu.unicamp.br/ ojs/index.php/etd/article/view/8638257/9849

Olsson, I., Hagekull, B., Giannotta, F., \& Ahalander, C. (2016). Adolescents and social support situations. Scandinavian Psychological Associations and John Wiley \& Sons, 31(1), 1-10. doi:10.1111/sjop.12282

Ortigão, M. I. R., \& Aguiar, G. S. (2013). Repetência escolar nos anos iniciais do Ensino Fundamental: Evidências a partir dos dados da Prova Brasil 2009. Revista Brasileira de Pedagogia, 94(237), 364-389. doi:10.1590/S217666812013000200003

Perrenoud, P. (2003). Sucesso na escola: Só o currículo, nada mais que o currículo. Cadernos de Pesquisa, 119, 9-27. Retrieved from http:// publicacoes.fcc.org.br/ojs/index.php/cp/article/ view/513/517

Souza, A. P., Ponczec, V. P., Oliva, B. T., \& Tavares, P. A. (2012). Fatores associados ao fluxo escolar no ingresso e ao longo do Ensino Médio no Brasil. Pesquisa e Planejamento Econômico, 42(1), 5-39. Retrieved from http://ppe.ipea.gov.br/index.php/ppe/article/viewFile/1322/1110

Squassoni, C. E., \& Matsukura, T. S. (2014). Adaptação transcultural da versão portuguesa do Social Support Appraisals para o Brasil. Psicologia: Reflexão e Crítica, 27(1), 71-80. doi:10.1590/ S0102-79722014000100009

Tian, L., Zhao, J., \& Huebner, E. S. (2015). Schoolrelated social support and subjective well-being in school among adolescents: The role of selfsystem factors. Journal of Adolescence, 45, 138148. doi:10.1016/j.adolescence.2015.09.003

Tomé, G., \& Matos, M. G. (2012). Relação positiva com grupo de pares na adolescência. In M. G. de Matos \& G. Tomé (Eds.), Aventura Social: Promoção de competências e do capital social para um empreendedorismo com saúde na escola e na comunidade (pp. 111-125). São Paulo, SP: Moderna.

Vaux, A., Phillips, J., Holly, L., Thomson, B., Williams, D., \& Stewart, D. (1986). The Social Support Appraisals (SS-A) Scale: Studies of reliability and validity. American Journal of Com- 
munity Psychology, 14(2), 195-219. doi:10.0910562/86/0400-0195505.00/0

Wang, M. T., \& Holcombe, R. (2010). Adolescents' perceptions of school environment, engagement, and academic achievement in middle school. American Educational Research Journal, 47(3), 633-662. doi:10.3102/0002831209361209

Womack, S. A., Marchant, M., \& Borders, D. (2011). Literature-based social skills Instruction: A strategy for students with learning disabilities. Intervention in School and Clinic, 46(3), 157164. Retrieved from http://journals.sagepub. com/doi/abs/10.1177/1053451210378164

Woolley, M. E., Kol, K. L., \& Bowen, G. L. (2009). The social context of school success for Latino middle school students: Direct and indirect influences of teachers, family, and friends. Journal of Early Adolescence, 29(1), 43-70. doi:10.1177/0272431608324.
Zambon, M. P., \& Rose, T. M. S. (2012). Motivação de alunos do ensino fundamental: Relações entre rendimento acadêmico, autoconceito, atribuições de causalidade e metas de realização. Educação e Pesquisa, 38(4), 965-980. doi:10.1590/S151797022012000400012
Received: 28/06/2016

$1^{\text {st }}$ revision: $13 / 02 / 2017$

Accepted: 28/02/2017

(C) The Author(s), 2018. Open Access. This article is distributed under the terms of the Creative Commons Attribution 4.0 International License (http://creativecommons.org/licenses/by/4.0/), which permits unrestricted use, distribution, and reproduction in any medium, provided you give appropriate credit to the original author(s) and the source, provide a link to the Creative Commons license, and indicate if changes were made. 